\title{
RETRACTION (GLOBAL ECONOMIC TERRORISM, FORMS AND THEIR IMPACTS)
}

\author{
Meirison \\ UIN Imam Bonjol Padang \\ email: meirison.a@gmail.com
}

Abstract: Terrorism is not only a matter of security and fear but terrorism is linked to national and global economies that have economic and social impacts. Economics and terrorism have interactional relationships. A role played by large capital owners composed of international companies spread all over the world laden with political interests. Terrorism is very harmful to developing countries that will never rise again because it has long joined the world economy consisting of giant companies capable of doing any research for the benefits and benefits dredged and assisted by banks, printed and electronic media, espionage, black market And sometimes underground economic. Capital, economy, technology is neutral but the owner of capital and investment is sometimes not neutral because capital has no state, but the country is capital market and investment. The movement of money and gold has been controlled by large corporations that can instantly devastate the economy of a country let alone a debilitated developing country and can no longer be analyzed by conventional economic theory.

الملخص: ليست مسألة الإرهاب هي مسألة الامن والخوف فقط ، بل الإرهاب مرتبط

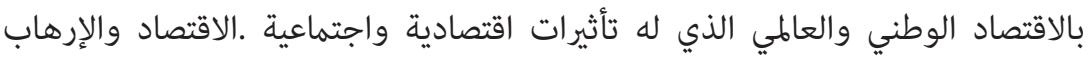

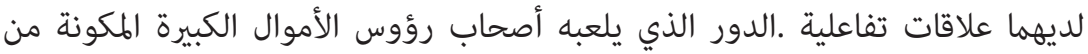

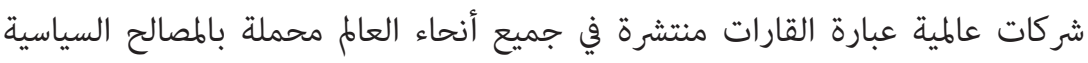

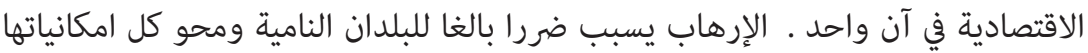

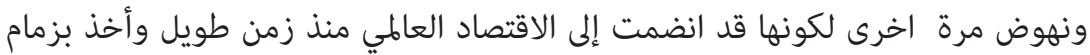


امرها وهي تتألف من شركات عملاقة قادرة على إجراء أي بحث علمي للفوائد الشتى

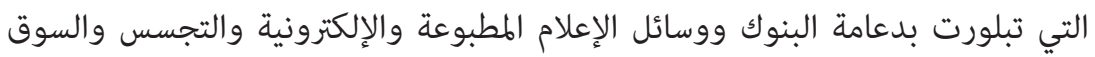

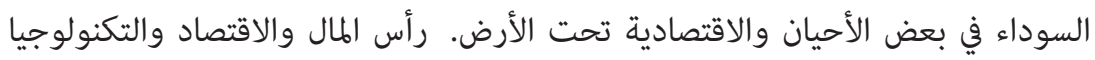

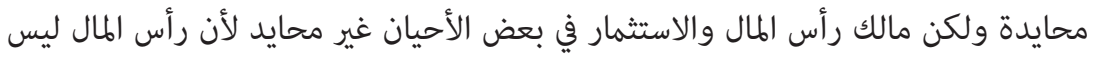

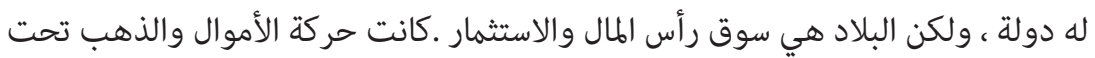

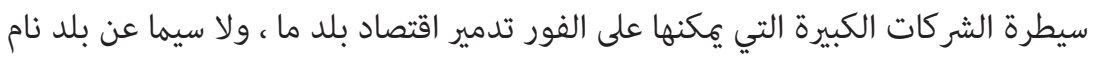
ضعيف ، ولم يعد من الممكن تحليله بالنظرية الاقتصادية التقليدية.

Abstrak:Permasalahan terorisme bukanlah sebuah permasalahan yang terkait dengan keamanan dan ketakutan semata. Terorisme terkait dengan ekonomi nasional dan dunia yang mempunyai dampak secara ekonomi dan sosial. Ekonomi dan terorisme mempunyai hubungan interaktif. Sebuah peran yang dimainkan oleh pemilik modal besar yang terdiri dari perusahaan besar dan kartel yang tersebar di seluruh dunia yang sarat dengan kepentingan ekonomi dan politik. Terorisme telah menebar kemudharatan pada negara-negara berkembang dan menghapuskan sekala yang dimiliki untuk bangkit. Hal ini disebabkan kuatnya kelompok ini melekat dan tergabung dalam ekonomi dunia yang kuat sejak dulu dan mengendalikannya sampai ke akar-akarnya. Ia terdiri dari perusahaan raksasa yang sanggup melakukan riset ilmiah apapun untuk menunjang segala kegiatannya. Ditambah lagi dengan dukungan bank-bank, media masa baik cetak maupun elektronik, spionase, pasar gelap, pasar bawah tanah (underground market). Modal dan ekonomi, teknologi adalah netral akan tetapi peilik modal dan investasi tidaklah netral. Modal tidak mempunyai negara. Negara modal adalah pasar modal itu sendiri, investasi. Pergerakan modal dan emas dibawah kendali perusahaan-perusahaan besar yang dapat dengan sekonyong-konyong menghancurkan negara manapun. Apalagi negara perkembang yang lemah dan hal ini tidak dapat dianalisa dengan teori ekonomi tradisional.

Kaywords: global economic, terorism, espionage, developing country, 


\section{INTRODUCTION}

The development of events in this world is very fast and astonishing. The events of terrorism, the social, economic, and new scientific revolution achieved by humans are astonishing and never crossed my mind. Not to mention an appalling event happening somewhere has not yet finished its echo everywhere there have been other events similar or more devastating than previous events. This way the movement of information and media can be delivered continuously in a short time. A group of companies that manage print and electronic media have mastered the information and economy of this century. Within an hour there have been many events that have become the center of attention for the scientific community. As educated people we should pay close attention to what really happens around us including economic, social and cultural issues. Events in this world will experience a very fast development, let us take the attitude and actions that should be done by providing solutions to such a very fast event. We live in an industrial age based on scientific science. That way we should also have the ability of scientific thinking trained. In this way developed and developing countries can produce its development and achievements to state its existence, and develop its knowledge effectively.

The fate of humanity and ethnicity will end up at least be threatened by the actions of hegemonic owners today. In this paper we will discuss the problem, the function of terrorism in the economy by explaining some of its forms and the effects and dangers of some of the following items Globalization and The invisible hand (invisible hand): ${ }^{1}$

1. Criminal acts of economic terrorism

2. The debt of economic terrorism

3. Militaryization of economic terrorism

4. The colonization of economic terroris

5. Espionage economic terrorism

6. Hiden economic (pseudo economic) Terrorism

7. Money laundering in economic terrorism

8. International companies and economic terrorism activities

${ }^{1}$ Zaid Rumani, z̧ahīāt Irḥab al-Duwal (Beirut: Dar al-Kutub al-Ilmiah, 2001), $17-19$. 
The phenomenon of economic terrorism is a very dangerous act that can destroy mankind: ${ }^{2}$

\section{GLOBALIZATION THE INVISIBLE HAND (THE ARTIFICIAL HAND)}

The mass media has proclaimed to us the good news that globalization and the bright future horizon will be enjoyed by the world's population at this time. Liquefaction and movement of money can be done in a very fast time like lightning in indefinite space and time. It can not be denied about the virtues and benefits of the currency since it was discovered in the 7th century BC. Money has made breaking up of brotherly ties and relationships, quarrels and anger. But money can also improve the situation and raise the standard of living and establish the truth. Banks have spread everywhere very quickly, with a vast network reaching all corners of the world with clients everywhere with high mobility. The enormous capital that can be availed at any time from Western financial institutions like an iceberg struck by the sun will glide like snow covering the entire surface of the ground beneath it, even more so. Even the capital itself is stronger than the countries in the world. The millions of billions of billions of dollars in the New York, London, Tokyo stock markets have been made thrones by the kings who have mastered them and some of the names of such capitalists as George Soros, lfred Winslow Jones, Waddill Catchings, Henry Kravis, Nick Leeson, Hyman Minsky, Michael Milken, Robert Vesco, Bill Gates and other names. They mobilize their capital according to their benefit and as they wish. Their benefits are linked to getting a rare opportunity and opportunity to swallow up competitors and rival companies. They also control the prices of goods and currencies, in order to gain multiple benefits from loans and receivables they provide to countries in need. They can also cancel the agreement for political reasons or provide economic recipes that have very adverse side effects to the economic health of a country they inject. They are the hidden armies that control the world economy, the free market, the laws and the rules of commerce that the world powers must obey. These predators prey without pity on either the victim who has power or powerless at all, will remain 15.

${ }^{2}$ Rizqullah Hailan, Mutaqaddimāat al-Iqtiṣādiyah (Dimasq: Dar al-Hisad, 1998), 
the target and the prey to be wiped out without the rest. In the nerves and minds they have attached to the love of greatness and power that continues to grow in line with the increase and achievement they get. They have provided direction and planning on consumption maps, investments that must be announced in the media they monopolize themselves. It is they who manage the media, when the information is raised and when the planning and steps of economic intervention should they hide from any media. The globalization brought about by the media is not as simple as what is portrayed and even the contrast of globalization is very complicated to understand if it has been seen several different lattices. Sometimes there is an opportunity to renew the capital and the sustainability of its hegemony over a market it has long held. On other occasions they have the opport unity to raise the value of shares and capital in the world market in accordance with SOPs that have been agreed upon either officially or in the hidden. While on another occasion is a situation that can be a trap both the owners of capital if he fall into it. ${ }^{3}$

Globalization calls for a decrease in the minimum wage for workers to win global competition. Globalization will also make the workers no longer have the honor of a human being who has all kinds and basic rights that he has since birth. Because workers have to hurry, and lie exhausted to pursue side income to ensure the life of their family in order to reach the level of consumption of modern society. Earnings that must be set aside to deal with the changing situation, he must demonstrate his expertise and patent rights in order to stand upright in front of today's hero that is the owner of the hidden hand (Invisible Hand). The saddest thing can be seen from the statistical data that the growth of poverty rate is increasing in this globalization era. The number of homeless children in the third world who eat rubbish has become hundreds of thousands. Children are used as spare parts, thousands of victims of terrorism are planned for the program of cleaning the area rich in natural resources. ${ }^{4}$

\section{CRIMINAL ACTS OF ECONOMIC TERRORISM}

The criminal act of terrorism provides a burden of losses that are not the least good moral and material losses. Additional costs to

${ }^{3}$ Rumani, zahīirät Irhab al-Duwal, 308.

${ }^{4}$ Rumani, 309. 
intelligence legal institutions. Moral loss can be felt by society in terms of humanity, social both individually and society.

No criminal terrorism has disrupted the world economy on a large scale. Awareness about the magnitude of the burden caused by terrorism is still not present in the countries that become victims. The paranoia in the costs incurred by terrorism in a country has been widely discussed but has different perspectives that have not yet been integrated into a standard conclusion. Sometimes direct losses affecting individuals, communities and infrastructure and the allocation of state budget funds due to terrorism. Terrorism also results in the scarcity of goods. Counting real numbers due to terrorism is quite difficult to do. Takaful in society to deal with terrorism is urgently needed. Can be distinguished direct economic losses due to this terrorism and indirect economic losses. Direct loss is the victim of life, property while indirectly is the cost of enforcing justice due to this terrorism which sometimes runs ineffectively. Let the community along with the government try to prevent the phenomenon of terrorism by eliminating its causes. ${ }^{5}$

\section{DEBT DUE TO ECONOMIC TERRORISM}

The world now lives in darkness in various shapes and colors of income from this world $75 \%$ centered on a quarter of the world's population while $25 \%$ are in the hands of poor countries. Debt problems are considered the most complicated issue of the modern era. The debt of third world countries has reached 1.4 trillion US Dollars according to UN reports at a meeting in Copenhagen. Most observers fear such a huge debt will be a weapon for rich countries in creating modern colonialism that has been going on for a long time. History will always be repeated but the actors and actresses, and the directors are different but the scenario is the old scenario played repeatedly. ${ }^{6}$

We can compare the world's financial and banking systems with past slavery systems. Workers in the slave system can not leave their jobs. Workers must work steadily to buy staple goods at very high prices, with very low wages from the same company.

\footnotetext{
${ }^{5}$ Abd al-Said Ismail, Terrorism and Economic and Their Impact on Currency (Kairo: Dar al-Nahdah, 2016), 103.

${ }^{6}$ Rumani, zahïrāt Irhab al-Duwal, 118.
} 
The purpose of the owners of the capital as well as the owners of the company and the creditors is not the repayment of the debt, nor does it make the workers hungry but the owners of the capital want their workers and the debtors to have a lasting engagement in order to be exploited on an ongoing basis. This system of slavery is prevailing throughout the world because it has been dominated by the global economy. The newly independent nation will find its country in a state of weakness, unable to finance its own needs. This will make the newly independent country will continue to depend on donor countries that are increasingly difficult to detach from them. If developing countries join and are in the global economic system, these countries will remain underdeveloped and will continue to be crippled and deceived by the perceived relative growth. Real growth has helped the growth of the global economy enjoyed by large capital owners. Once the capital is transferred in large quantities caused by various factors the impact is to increase the financial crisis in Muslim countries. Some of the capital possessed by the Islamic world is invested in developed countries with an amount not less than 700 billion US dollars. ${ }^{7}$ says (the movement of capital from developing countries to developed countries is like a blood transfusion done to the sick to the fit. ${ }^{8}$ says the weakness of developing countries And the global economic system will permanently create a developing country that will not be able to rise forever and remain a slave to the industrialized countries.Try to protect domestic trade and develop economic capabilities undertaken by developing countries to become self-reliant is terrorism Economy. ${ }^{9}$

\section{THE MILITERATION OF ECONOMIC TERRORISM}

Humanity in a state of danger, because humans in the past have not possessed weapons of mass destruction but now people have been competing in melikinya. Violence must exist in the life of the state as where violence also exists in the life of the individual, but the international condition with the existence of globalization has removed the peace because of the lack of balance of power.

${ }^{7}$ Fili Brant, Law and Economics Issues in Subprime Litigation (Venice: University Press, 2008), 36.

${ }^{8}$ Ismail, Terrorism and Economic and Their Impact on Currency, 103.

${ }^{9}$ Hailan, Mutaqaddimāat al-Iqtișādiyah, 15. 
Spending on weapons production is more than 550 billion US dollars per year. To produce the weapon has employed more than 400,000 experts which means $40 \%$ of experts and experts have focused on weapons manufacture. The industrialized countries are the cause of the widespread production of weapons of mass destruction and have created sustained disputes in developing countries. Various weapons have been created including the results of Japanese research in China before the second world war was adopted by the United States (Unit 371), research submitted as compensation for the discharge of Emperor Hirohito to be hung in the San Francisco United States at that time became the UN headquarters. The weapon is a toxic gas weapon that is far more devastating and deadly on a wide scale. During World War II, the arms production and development race reached its peak, employing women and children to produce the first Jet aircraft in Germany and U Boat submarine. But the allies gathered all the experts to create a new weapon to be used in Hirosima and Nagasaki which is a small model of terrorism compared to what is happening and is expected to happen in the future.

\section{COLONIAL ECONOMIC TERRORISM}

Muslims have gained favorable news with the release of Muslim countries from physical colonization in the form of military occupation by the countries of Western and Eastern invaders. But the colonizers did not go away. They leave a strong influence on the nation they left behind and made it bound by its terms and laws. Natural resources of ex-colonial countries can be exploited at any time. They hide behind the slogans of development and economic development with monopoly mega-projects controlled by foreign nations. The prevailing economic pattern is very detrimental to Muslims, low per capita income, chronic and continuous problems continue to occur. The national product has never improved, the Islamic world has no independent technology industry. The life of the Muslim community in any country of the world is merely consumptive unless only a few of these countries seek to rise from the economic colonization which is very difficult to escape from it. The form of colonization that can be felt one of them is the creation of a fake image imaging. Which later became puppets, insurrection engineering, and other political plots. This causes the balance of payments in the Islamic world to 
experience big problems. The Islamic world has become a cash cow for capitalist capitalists, so the doors of sustenance for those who do not belong to their group become more difficult to open. Muslims have been forced to eat the haram, then the invaders have eliminated the minds of Muslims which are lawful and which are haram. The Capitalist economic system of the West has succeeded in controlling almost the entire world economy including the Islamic world, so there is no longer any opportunity for Muslims to move a bit. The economic impact of colonialism in the Islamic world is very much that continues to make an impression on the present: ${ }^{10}$

1. Invaders allocate natural resources for special welfare. Foreign capital is used to fund the war and then dredge the wealth that exists in these countries, foreign companies serve as the managers of the benefit of the invaders. Thus other financial and economic institutions such as the Bank have been the catalysts for the mutation and regulation of gold owned by the West at the end of the nineteenth century. The West has devoted all their capital and resources to produce consumptive, tertiary goods which Then marketed to an avid Islamic world with these products coupled with ads that are very tempting and intensive. Not only is there Western banking institutions offering ease of lending to the governments of developing countries including the ensuing Muslim countries and as compensation is that the country sells and delivers its natural resources at a price that very cheap.

2. The monopoly of trade in foreign trade is also carried out by the countries of large capital owners. Especially Western countries. They have also mastered domestic trade. In Muslim countries like North Africa they market products not only by trade but also by permanently settling with thousands of representatives in the region down to the Arabian Peninsula and to Southeast Asia this ends in a more efficient way with Producing their commodities by holding the patents and the portion of the profits that have been arranged for submission to cheap labor in China.

3. Major industrialized countries are always trying to shut down the domestic industries in the Islamic world as it has done to IPTN, PT PAL and other industries no different from those done in the Middle East or in other parts of the Muslim world. This is done

${ }^{10}$ Ainur R. Shopian, Etika Ekonomi Politik (Surabaya: Risalah Gusti, 1997), 168. 
to ensure that these countries remain dependent on the West in everything, both economic, military and cultural.

4. Monopoly control of natural resources in the Islamic world, especially minerals and mines, such as petroleum, gold, iron and copper to uranium. The occupiers have long since abandoned Muslim countries but are replaced by big companies.

5. The economic invaders supported an integrated rice field and management system that made the Muslims unable to enjoy the plantation and agricultural products.

This is partly the impact of the colonization of Western economies that penetrated the whole Islamic world. They have produced all the tools to accelerate the natural resource exploitation mechanisms that make Muslims always dependent and economic terrorism continues to grow and flourish.

\section{ESPIONAGE AND ECONOMIC TERRORISM}

Economic espionage is a tool and media that is already a liability for every capital owner and large industrial companies. This espionage has been practiced since time immemorial, the agent is officially recognized but works clandestinely. Today the issue is no longer a political balance and power between rulers and rulers, nor is the balance of rights to be heard for justice but has become the balance of the good to survive. We live in a struggle that determines the fate of mankind and the nations. Once the economy becomes transparent then everything has become transparent. Economics is the power and the basis of state and government mobility therefore economic espionage has an important role in developing countries and institutions, projects in this modern age. A role that can not be ignored. At present there is no self-sufficient country, or it can be self-sufficient. To meet the needs of a country trying to get it barter. Whether it's raw materials, human resources, and capital or management systems. All these aspects are part of national production, be it agriculture, industry, banking or public services. The profession of espionage or economic spy has become a profession and occupies an important position in the development of world economy. Espionage has the first dual function is a security function to keep secrets potentially leaked by the enemy, such as phototype, blueprint and any kind of secret government policy. And conversely spy function externally is 
to get information about the activities of enemies or rivals either in the form of technical or policy. The important information that is usually sought by this economic espionage is: ${ }^{11}$

1. What will happen in the short and long term?

2. What are the shortcomings and strengths and potentials and planning of other industry sectors?

3. How can we influence and control others micro and macro?

4. To what extent can the opponent's power control economic and non economic factors within an entity or entity.

\section{UNDERGROUND ECONOMY AND ECONOMIC TERRORISTS}

The phrase used for the pseudo economy is Under Ground Economic, which is parallel economy, informal economy, dark economy, underground economy. The underground economy conducts clandestine activities and can not be officially detected and exists in government economic activity. Including unreleased legal production in sectors, industrial agriculture, development projects, domestic trade, tourism, hospitality, transportation and cargo, finance and insurance, public and social services. Some economists exist that support the underground economy because it has advantages of several sides and also has shortcomings from the other side. The underground economy can improve the welfare and standard of living in certain situations, usually of a limited nature. ${ }^{12}$ Some economists argue that the underground economy will have an adverse effect on companies in the government sector as it will incur extra costs. Workers get additional jobs on the other hand decreased worker productivity in public companies. Thus the wages of workers received more lace from the official wage (UMR). This will obviously affect the national income. It is no secret that there is a connection between the real income achieved in the underground economy and local and international terrorist activities and support for perpetrators of violence worldwide. Given the economic linkage of the underground with economic crime, the domestic ministries in some countries of the world established a special body to arrest the perpetrators of money laundering, and reveal the linkage of economic crime perpetrators

\footnotetext{
${ }^{11}$ Muhsin al-Khudhari, Al-Jasūiyat al-Iqtișād (Kairo: Dar al-Aqaid, 1992), 17.

${ }^{12}$ Zaid al-Rumani, Al-Nawāfiz al-Iqtișādiyah (Riyadh: Dar al-Thariq, 2001), 120.
} 
with terrorism. Many countries have sought to cooperate in tackling economic crimes but have little to do with terrorism. A study has explained the profitability of mafias resulting from the darker chapters of some countries having reached $50 \%$ of the national income (GNP). Some even get information about the profits of the underground economy has earned about 110 billion US dollars. This has clarified the role of the underground economy that has controlled the economy of a developing country through black markets in different parts of the world. However, developed countries are also experiencing the same thing still feel the impact of this underground economy. Money laundering is increasing year by year around the world in accordance with existing monetary developments. Economic actors that land, drug traffickers and money-laundering brokers have been able to increase their revenues through black market and currency trading, gold trading, liquor, gambling, prostitution and drugs. ${ }^{13}$

\section{MONEY LAUNDERING AND ECONOMIC TERRORISM}

Drug traffickers have invested in property by moving their capital abroad through foreign investment companies. This company exists in countries that are easy to hide. So that core companies can not be examined against it. Then the stealth company again made loan transactions to recycle capital which was then handed over to the smugglers and drug traffickers. UN records in money laundering carried out by underground economic actors and drug traffickers and black market managers have reached 120-500 billion US dollars. It is unfortunate that companies that engage in money laundering practices, both foreign and local, are very difficult for the government to audit its documents, especially financial reports and transactions. The company is engaged only in the field of money laundering that comes from drug transactions, gambling, prostitution and all kinds of crimes. This company can camouflage by moving in property and investment. This money laundering is known as white-collar crime. An activity laden with unlawful acts, such as corruption and other forms of crime that include $:^{14}$

${ }^{13}$ Hamdi Abdul Azim, Al-Iqtiṣād al-Alam fi Ma'ziq (Beirut: Dar al-Qalam, 2009).

${ }^{14}$ Azim, 38-44. 
1. Illicit trading activities consist mostly of imported products without paying import duties, prostitution, and trafficking networks.

2. Smuggling, goods and weapons through borders, illegal markets and illegal currency trading, illegal granting of visas by criminals who fled from other countries.

3. Smuggling of counterfeit money and securities and withdrawing in destination country. Money laundering has become a master weapon that not only applies in third world countries but also mushroomed in developed countries that cause problems. Unlike the underground economy that is not recorded or recorded by the government is not necessarily a criminal act. Unlike the case with money laundering that clearly has legalized money the results of unlawful acts and norms and morals. Sometimes this underground economy has played a role in reducing the government duty in providing jobs and producing the needed goods only such products are not recorded. While money laundering is one form of modern economic terrorism. ${ }^{15}$

\section{INTERNATIONAL COMPANIES AND ACTIVITIES OF ECONOMIC TERRORISM}

International Company, Intercontinental, has grown rapidly, this is a new phenomenon in the world of economy, politics and social, the government is required to play its role in controlling the balance of this company's activities for the benefit. They produce a wide variety of goods and services, whose factories are located all over the world employing very large and inexpensive labor. This activity will affect the relations between countries both economic, political and cultural both in terms of positive and negative that must be considered by the countries involved in accordance with the size of its small role. For example, General Motors, Shell, Esso, IBM, Philips, these companies can no longer be mentioned in certain countries because their products are not from one country. Its products come from various countries and are marketed with a system that is constantly evolving and refining over time across countries and continents. These companies have an enormous turnover that can exceed the

\footnotetext{
${ }^{15}$ Andrew Blowers dan G. Thompson, Ketidakmeratan, Konflik dan Perubahan,
} Terjemah Paul Sitohang (Jakarta: UI-Press, 1983). 
wealthiest countries in Europe even with very fast growth. A number of reports have been made about this transnational company that the company has made a profit of about 90 billion dollars, of which one third comes from industrialized countries while the rest comes from developing countries. ${ }^{16}$ This figure is the old number, the percentage of investment of multinationals continues to increase by $12 \%$ per year. Thus in the early $70 \mathrm{~s}$ the number had reached 150 billion dollars, 250 billion dollars in the 80s. While in 2003 has reached 300 billion dollars. Multinational corporations have become a major force because of their growth rates doubling the growth of advanced industrial countries in Europe. ${ }^{17}$ Researchers have stated that the achievements that multinational corporations have realized in one year have reached $\$ 500$ billion - 1/5 of the national production of each country in the world. This information and data suggests how big the role of multinational companies and their impact on the world economy. These big companies greatly maintain their confidentiality in investment information, operations, profits, currency exchange. The managers of this company avoid the debate and research on company information whether committed by individuals or institutions submitted in scientific seminars. Because the owners of these companies are aware that the information obtained by researchers and the public will endanger the company and will also draw the attention of the government to direct its attention to the activities of the company. That way the company is no longer free to move that will obviously disrupt the company's own benefit. ${ }^{18}$

The magnitude of multinational corporations in accordance with their production that has a captive market worldwide, with large funds, extensive experience has allowed this company to conduct any research. The company is capable of brain bombing or the transfer of experts and experts in various fields in the third world to the United States.Mastery of some international companies in the field of engineering has penetrated the mastery in the political, social. Therefore, these companies have played a political role as compensation for the technological advances they have served. Transnational corporations are a centralized company in full control

\footnotetext{
${ }^{16}$ al-Rumani, Al-Nawāfiz al-Iqtiṣādiyah, 118.

${ }^{17}$ al-Rumani, 20.

${ }^{18}$ Shopian, Etika Ekonomi Politik, 116.
} 
of all subsidiaries spread all over the world. The parent company is like the brain and the central nervous system that controls all the organs. The company is always growing which then becomes a giant company. Howard Berluther says ("the world has been in the hands of some international corporations that range from about 500 to $600 .{ }^{19}$ These big companies invest and lend to third world countries with all the unfavorable, At all, but as a result of many factors the loan is still done.Even the profits dredged by these international companies is greater than the profits derived from the developed countries. The cause of the growth of this company are the principles adopted by the company that is capitalist principles (The capital has no state but the country is the investment market.) The principles of riba are very prominent in these transnational corporations. These companies control the value of currency and international banking. The savings and loan companies are not engaged in finance Which is clean but he engineered the condition of the world's gold reserves, and used the reserves according to their rules of play. So that in an instant it can destabilize the economies of poor countries which then fall in the grip of the world's ruling organizations. ${ }^{20}$

International companies have controlled $50 \%$ of world trade, which markets $90 \%$ of basic goods to poor countries with the rest marketed to the second world. The industrialized countries are the owners of these multinational corporations while the extension of their hands in the form of capital and currency moves freely through these multinational corporations. Can be seen in decades of investors and savings and loan companies have generated profits from lending rates nearly tripled. A worldwide system is a ribawi system that has advocated the southern half of the world in other words making the underdeveloped country no longer rises with a double loan that has been conditioned to no longer do anything. The destruction of a society for the resurrection of other peoples, the destruction of the continent for the resurrection of another continent, is diluted by the layers of society for the rise of other layers, wiped out by monopoly to preserve a wider monopoly and greater scope. Multinational companies will not be known before we can get to know the impact

${ }^{19}$ Syaikh Salih Kamil, Tațawur al-Amal fi Mașārif al-Islām Mashākil wa Afaq (Kairo: Bank al-Islami wa Tanmiyah, 1977).

${ }^{20}$ Sami Habil, Niz̄àm al-Murāb al-Alam (Dimasq: Dar al-Mustaqbal, 1991), 28. 
it left behind. The impact left by these multinational corporations is not only limited to the economies of a single country or continent but has penetrated deeply into politics and societies. The Overseas Company is the largest and most prominent investment company in the world that started operations after World War II. ${ }^{21}$

The standards and benchmarks used by this company are the volume of world production. In accordance with the purpose of capital and investment has no country but the country is the capital market and investment itself. United Nations Conference and Trade Development, has issued a statement about the hegemony of these companies in the $80 \mathrm{~s}$, the world cotton business has been controlled as much as $90 \%$ by 15 major companies of the world. Three companies have controlled $75 \%$ of the world's banana trade, while the chocolate trade has been controlled $75 \%$ by five companies while tobacco is controlled by $90 \%$ by six companies to produce cigarettes. ${ }^{22}$ In the millenium century the losses of developing countries increased due to the hegemony of the company, losses of developing countries reached 50-100 billion US dollars per year. The UN statistics table indicates the magnitude of the role played by these multinationals in the import sector in developing countries as much as $85 \%$ which consists entirely of food commodities. While the trade in their raw materials has contributed $90 \%$ and $95 \%$ of the management of mining, iron, gold, copper and uranium including petroleum. The problem is the development of technology in the world in line with the development of multinational companies. ${ }^{23}$ Not as expected that technology should be used to simplify the life of society but has turned into a tool of exploitation and exploitation of nations living in developing countries. These companies seek to unite the world market systematically and operate in a monopoly. The worrying activity of these companies is that technological equipment of any kind has become a trade and not as a positive positive scientific tool for mankind. This will change the mindset of people who are in consumptive importing countries. Moreover, the potential for exploiting technology for developing countries will be even smaller as its position is merely a consumptive

${ }^{21}$ Muhammad al-Sayid Abdussalam, Al-'Amn al-Ghizai li al-Wațān al-'Arabi (Kuwait: Mathabi' al-Risalah, 1993), 21.

${ }^{22}$ Al-Rumani, Al-Nawāfiz al-Iqtișādiyah, 16.

${ }^{23}$ Al-Rumani, 103. 
country that has never applied the science learned in established and operated universities at enormous expense. The United Nations Conference on Trade and Development describes the results of the research that the investment project and the impact it caused by the use of technology were a negative impact.

\section{CONCLUSION}

New World order, or a new world system, in fact there is nothing new, when there is strong spiritual restraints, clear moral values. They impose the will of thought and ideology, its laws upon society. Which country is the luckiest who has material, military power and never attempts to impose charges on the world already in his hands ?. The effort is in sight that we can see and hear through print and electronic media that are mostly misleading, to collect widespread treasures everywhere in the places they want. This is not a new thing by calling it a new world system. It may be that the so-called new incessant print and electronic media play a role in the activity, to camouflage against the crimes they committed. Is it called something new when the wealth of the weak is collected collectively by the strong and belongs to the strong ?. Economics in the real sense is not just a matter, it is a certain media that can explain many events in history. Not many changes have occurred just robbery has been run effectively and quickly with a lot of treasure and can be stored in a bag that is smaller and more practical. Activities based solely on the merits and benefits of rules and norms and forgetting the social dimension of economic activity are a great danger. Have not we now become prisoners of the elected group in the era of globalization. They have found a way to master millions of dollars in minutes or hours. Are we going to enter world governance once the concentration of wealth is completed in a narrow allocation ?. The abyss of poverty will gap the difference between the rich and the poor will become more real. The emergence of jealousy, against the economic bats that always sucks blood. 


\section{REFERENCES}

Abdussalam, Muhammad as-Sayid. Al-'Amn al-ghizai li al-Wațān al-'Arabi. Kuwait: Mathabi' ar-Risalah, 1993.

Azim, Hamdi Abdul. al-Iqtishad al-Alami fi Ma'ziq. Beirut: Dar alQalam, 2009.

Blowers, Andrew, dan G. Thompson. Ketidakmeratan, Konflik dan Perubahan, Terjemah Paul Sitohang. Jakarta: UI-Press, 1983.

Brant, Fili. Law and Economics Issues in Subprime Litigation. Venice: University Press, 2008.

Habil, Sami. Niz̄ām al-Murban al-Alami. Dimasq: Dar al-Mustaqbal, 1991.

Hailan, Rizqullah. Mutaqaddimāat al-Iqtișādiyah. Dimasq: Dar alHisad, 1998.

Ismail, Abd al-Said. Terrorism and Economic and Their Impact on Currency. Kairo: Dar al-Nahdah, 2016.

Kamil, Syaikh Salih. țatawur al-Amal fi Mașārif al-Islām Mashākil wa Afaq. Kairo: Bank al-Islami wa Tanmiyah, 1977.

Khudhari, Muhsin al-. al-Jasusiyah al-Iqtishadi. Kairo: Dar alAqaid, 1992.

Rumani, Zaid. żahirāt Irḥab al-Duwal. Beirut: Dar al-Kutub alIlmiah, 2001.

Rumani, Zaid ar-. Al-Nawāfiz al-Iqtișädiyah. Riyadh: Dar at-Thariq, 2001.

Shopian, Ainur R. Etika Ekonomi Politik. Surabaya: Risalah Gusti, 1997. 